\title{
Apoptotic and Nonapoptotic Caspase Functions in Animal Development
}

\author{
Masayuki Miura \\ Department of Genetics, Graduate School of Pharmaceutical Sciences, University of Tokyo, \\ and CREST, JST, 7-3-1 Hongo, Bunkyo-ku, Tokyo 113-0033, Japan \\ Correspondence: miura@mol.f.u-tokyo.ac.jp
}

\begin{abstract}
A developing animal is exposed to both intrinsic and extrinsic stresses. One stress response is caspase activation. Caspase activation not only controls apoptosis but also proliferation, differentiation, cell shape, and cell migration. Caspase activation drives development by executing cell death or nonapoptotic functions in a cell-autonomous manner, and by secreting signaling molecules or generating mechanical forces, in a noncell autonomous manner.
\end{abstract}

$P^{r}$ ogrammed cell death or apoptosis occurs widely during development. During C. elegans development, 131 cells die by caspase CED3-dependent apoptosis; however, ced-3 mutants do not show significant developmental defects (Ellis and Horvitz 1986). In contrast, studies on caspase mutants in mouse and Drosophila have revealed caspases' roles in development. During development, cells are exposed to extrinsic and intrinsic stresses, and caspases are activated as one of multiple stress responses that ensure developmental robustness (Fig. 1). Caspases actively regulate animal development through both apoptosis and nonapoptotic functions that involve cell-cell communication in developing cell communities (Miura 2011). This chapter focuses on the in vivo roles of caspases in development and regeneration.

\section{INITIATOR CASPASES}

\section{Caspase-8}

Caspase-8 is a death-effector domain (DED)containing initiator caspase, initially found as a component of the Fas/Apo-1 death-inducing signaling complex (DISC) (Muzio et al. 1996) and a MORT1/FADD-binding protein (Boldin et al. 1996). Caspase-8-knockout mice are lethal at embryonic day (E) 11.5 (Varfolomeev et al. 1998; Sakamaki et al. 2002; Kang et al. 2004). At E10.5, abnormal yolk sac vasculature is observed, followed by various defects in the developing heart and neural tube (Varfolomeev et al. 1998; Sakamaki et al. 2002). Mutant embryos show hyperemia in the superficial capillaries and other blood vessels, and extensive erythrocytosis in the liver. These defects result in severe

Editors: Eric H. Baehrecke, Douglas R. Green, Sally Kornbluth, and Guy S. Salvesen

Additional Perspectives on Cell Survival and Cell Death available at www.cshperspectives.org

Copyright (C) 2012 Cold Spring Harbor Laboratory Press; all rights reserved; doi: 10.1101/cshperspect.a008664

Cite this article as Cold Spring Harb Perspect Biol 2012;4:a008664 
M. Miura

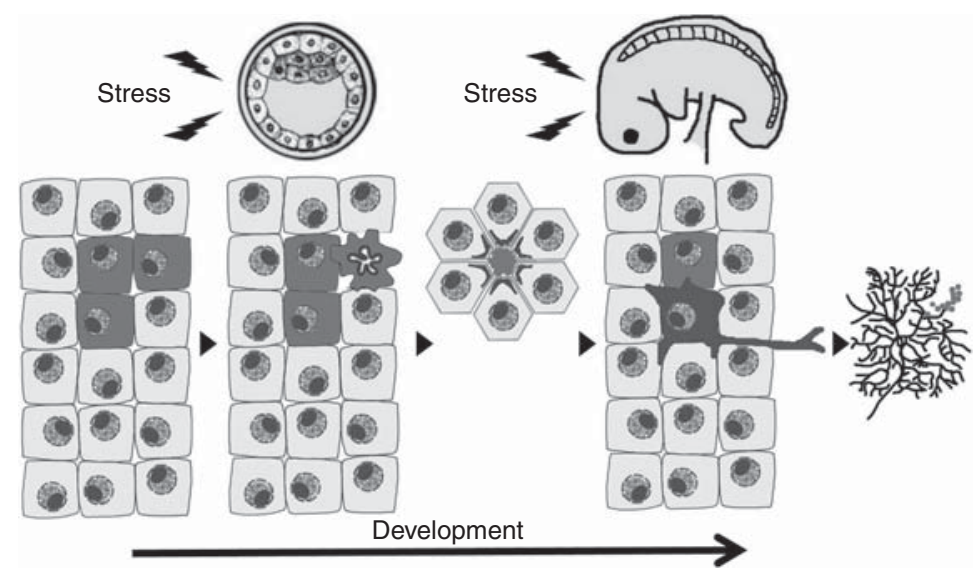

Figure 1. Caspase activation during development. An embryo undergoes intrinsic and extrinsic stress, which activates caspases to execute both apoptotic and nonapoptotic functions, including cell differentiation and dendrite pruning. Apoptotic cells affect the shape and behavior of their neighboring cells. Caspase-activated cells are shown in dark gray.

primary or secondary depletion of the hematopoietic precursor pool. Mutant embryos also show impaired heart muscle development (Varfolomeev et al. 1998).

The homozygous mutant neural and heart defects are rescued by ex vivo whole-embryo culture during E10.5-E11.5 (Sakamaki et al. 2002), suggesting that the mutant phenotypes of the neural tube and heart are caused by secondary effects of impaired angiogenesis in the yolk sac. Consistent with this idea, endothelium-specific caspase-8-knockout mice show the same phenotype as conventional knockout mice (Kang et al. 2004). Whereas knockout mice of Fas, TNFR1, DR3, or TRAIL are viable (Pfeffer et al. 1993; Rothe et al. 1993; Adachi et al. 1995; Liu et al. 2001; Wang et al. 2001; Cretney et al. 2002), FADD- and cFLIPL-deficient mice show the same phenotypes as caspase-8-knockout mice (Yeh et al. 1998, 2000; Zhang et al. 1998). Thus, the caspase- 8 developmental phenotype does not seem to depend on any single death ligand or receptor.

Recent studies revealed that caspase-8/ FADD pathway has an important role in suppressing RIPK1/RIPK3-mediated necrosis (necroptosis). Deletion of RIPK1 or RIPK3 rescued lethality of FADD or caspase-8 deletion (Kaiser et al. 2011; Oberst et al. 2011; Zhang et al. 2011).
The inactivation of RIPK1 or RIPK3 through caspase-8-mediated cleavage may be required for the protection of cells from necroptosis, thus caspase- 8 deletion can activate necroptosis pathway during development (Feng et al. 2007; Cho et al. 2009).

Caspase inhibitors (pan caspase-inhibitor Z-VAD, baculovirus p35, or cowpox virus CrmA) block macrophage differentiation and activation (Sordet et al. 2002) in vitro. This finding and studies in myelomonocytic-lineagespecific caspase-8-knockout mice suggest that the M-CSF-stimulated differentiation of macrophage precursors is caspase-8-dependent. In the absence of caspase-8, such precursors are eliminated by apoptosis, indicating that caspase- 8 has a prosurvival role (Kang et al. 2004). Upon M-CSF stimulation, caspase- 8 mediates cleavage of serine/threonine kinase receptor-interacting protein 1 (RIPK1), which prevents the sustained activation of NFKB and leads to macrophagic differentiation (Rebe et al. 2007).

Signal exchanges among epidermal keratinocytes, dermal fibroblasts, and leukocytic cells are critical regulatory mechanisms for skin homeostasis and wound healing. These reciprocal interactions are initiated by the paracrine signaling of interleukin $1 \alpha$ (ILl $\alpha)$, which activates both skin stem-cell proliferation and 
cutaneous inflammation. During wound healing, caspase- 8 expression is downregulated in the epidermal granular layer, after which a p38-MAPK-mediated upregulation of NLRP3 leads to inflammasome assembly and caspase1 activation, resulting in the noncanonical secretion of IL1 $\alpha$ from epidermal keratinocytes (Lee et al. 2009b). Mature IL1 $\alpha$ stimulates NFкB, which leads to growth arrest and promotes keratinocyte survival. IL $1 \alpha$ also stimulates dermal fibroblasts to secrete secondary factors such as KGF and GM-CSF, which signal back to the epidermis to induce keratinocyte proliferation in the basal layer. Caspase-8's importance is supported by the observation that caspase8 -deficient skin shows epidermal hyperplasia (Lee et al. 2009b). The chronic loss of epidermal caspase- 8 in mice enhances wound-healing responses and recapitulates atopic dermatitis ( $\mathrm{Li}$ et al. 2010a). Consistent with this, caspase- 8 is increased in diabetic mice in which wound healing is impaired (Al-Mashat et al. 2006).

\section{Caspase-9 and Dronc}

Caspase- 9 and apaf-1 are key components of the intrinsic, mitochondrial apoptosis pathway. On a mixed 129/SvJ background, the knockout of apaf- 1 or caspase- 9 causes similar developmental defects, including neural-tubeclosure (NTC) defects in the hindbrain and enlarged ventricular zones in the fore- and midbrain (Cecconi et al. 1998; Hakem et al. 1998; Kuida et al. 1998; Yoshida et al. 1998). Live imaging of caspase activation in cultured mouse embryo revealed the detailed apoptotic process of NTC. Two types of caspase-activated cells appeared during NTC. One is a typical apoptotic cell (classical [C]-type), and the other is an atypical apoptotic cell (dancing [D]-type), which does not show cell fragmentation and remains and dances around their original sites for a long period. Capsase-activation kinetics in D-type is slower than in C-type and caspase-7 is selectively activated in D-type. Apaf1-deficiency abolished the appearance of both C- and D-type cells, and delayed the progression of neural tube closure. Thus inhibition of apoptosis could cause the NTC defect and in- crease the risk of exencephaly (Yamaguchi et al. 2011).

Semaphorin 7A (Sema7A) that can promote axon guidance and neuronal migration in neural development is a direct substrate for caspase-9 (Ohsawa et al. 2009). Caspase-9 and apaf1 mutant mice show misrouted axons, impaired synaptic formation, and defects in olfactory sensory neuron (OSN) maturation without changes in the OSN cell number (Ohsawa et al. 2010). Thus, some developmental abnormalities resulting from caspase inhibition could be attributable to the loss of a nonapoptotic function of caspase-9.

Dronc is a Drosophila ortholog of caspase-9/ CED-3, and the only CARD-containing caspase in Drosophila. The dronc mutation abolishes most of the programmed cell death during development and causes pupal death (Chew et al. 2004; Daish et al. 2004; Waldhuber et al. 2005; $\mathrm{Xu}$ et al. 2005; Kondo et al. 2006). Dronc is essential for diap1-degradation-induced cell death (Leulier et al. 2006), compensatory proliferation, and dendrite pruning, described below.

\section{EXECUTIONER CASPASES}

\section{Caspase-3, Caspase-7, Drice, and dcp-1}

Caspase-3 deficiency in the 129/SvJ mouse causes neurodevelopmental abnormalities, including an expanded ventricular zone, ectopic neural structures, and gross brain malformations, as observed in caspase-9- or apaf-1-knockout mice (Kuida et al. 1996; Leonard et al. 2002). Caspase- 3 and caspase- 7 are both categorized as executioner caspases, although their substrate specificity is somewhat different. Caspase-7 is a more selective protease than caspase-3 (Walsh et al. 2008). The developmental defect of executioner caspase, apaf- 1 and caspase- 9 , is straindependent in mice. C57BL/6-dominant background mice with a single knockout of caspase-3 or caspase-7 do not show severe developmental defects and have a normal life span; however, mice with double knockouts of caspase-3 and caspase-7 (DKO) die shortly after birth, indicating that these caspases have redundant roles in embryonic development (Leonard 
M. Miura

et al. 2002; Lakhani et al. 2006). A small percentage $(\sim 10 \%)$ of them showed exencephaly, but the investigators assumed that this was attributable to residual genes from $129 / \mathrm{SvJ}$ background, as the DKO mice were backcrossed only six generations onto $\mathrm{C} 57 \mathrm{BL} / 6$ background, which was probably insufficient to remove all of the residual genes from 129/SvJ background (Lakhani et al. 2006). Most of the DKO mice did not show any sign of exencephaly and their cause of death after birth was unclear but might be caused by defective heart development. Caspase-7's in vivo function has not been extensively studied, but evidence suggests it regulates inflammation and pathological cell death (Teixeira et al. 2008). Caspase7 , but not caspase-3, is a direct substrate for caspase-1 (Lamkanfi et al. 2008), and caspase7 is involved in the induction of Legionella pneumophila-infected macrophages (Akhter et al. 2009).

Drice is a caspase-3 ortholog in Drosophila, in which it is the most abundantly expressed effector caspase (Fraser and Evan 1997; Kumar and Doumanis 2000). Drice mutants show pupal lethality and significantly decreased apoptosis during development, but the reduction is not as severe as in dronc mutants (Kondo et al. 2006; Muro et al. 2006; Xu et al. 2006). This is because drice shares functional redundancy with the other executioner caspase, dcp-1. $d c p-1$ mutants are viable and fertile (Kondo et al. 2006; Muro et al. 2006; Xu et al. 2006). drice/dcp-1 double mutants phenocopy dronc mutants, indicating that these two executioner caspases are functionally redundant, downstream of dronc (Kondo et al. 2006).

During metamorphosis, caspases are induced and activated by ecdysone, and most larval tissues including the salivary gland, midgut, and larval epidermis, are removed (Baehrecke 2000; Takemoto et al. 2007). p35 expression can only partially suppress the salivary-gland cell death; the inhibition of autophagy is required to block tissue degeneration completely (Berry and Baehrecke 2007). Despite high caspase activity in the midgut, autophagy but not caspase activity is essential for the programmed midgut cell death (Denton et al. 2009).
Caspase-Mediated Apoptosis in Fine-Tuning Neural Cell Populations

Large numbers of cells are thought to be eliminated by apoptosis in neural development (Buss et al. 2006). Live imaging enables a death-fated cell to be monitored throughout its lifetime. During sensory organ development of the Drosophila notum, about $20 \%$ of the differentiating neural cells die (Koto et al. 2011). Detailed observations of these cells indicate that the excess neural progenitors do not die in a random manner; instead, which proneural gene neuralizedpositive cells die follows a rule and depends on the Notch-activation level. Thus, Notch-regulated apoptosis of aberrant, mis-specified sensory organ precursor (SOP) mediates the finetuning of SOP cell selection (Koto et al. 2011). It has been proposed that apoptosis-mediated cell selection eliminates harmful autoreactive lymphocytes in primary lymphoid tissues (Strasser et al. 2008). Thus, apoptosis-mediated errorcorrection systems may be critical for eliminating aberrant cells, achieving normal development, and maintaining tissue homeostasis.

\section{Caspases in Morphogenesis}

One of the most fundamental roles of cell death during development is in tissue sculpting. However, none of the mouse mutants of core regulators of apoptosis, except for bax/bak doublemutant mice or bid/bim/puma triple mutant mice, show severe defects in morphogenetic cell death, such as the classic example of interdigital tissue removal (Lindsten et al. 2000; Ren et al. 2010). Furthermore, although cultured cells from apaf-1, bax/bak, or bid/bim/puma mutant mice have significant defects in cellstress-induced apoptosis, apaf-1, bax/bak, or $\mathrm{bid} / \mathrm{bim} /$ puma mutant mice generally develop into mostly normal adults, depending on their genetic background (Chautan et al. 1999; Lindsten and Thompson 2006; Ren et al. 2010). These results indicate that caspase-mediated apoptosis is dispensable, or that an alternative cell-death mechanism removes cells when the apoptotic machinery is inhibited. In fact, nonapoptotic cell death is observed in the interdigital 
region and other areas in apaf- 1 mutant mice (Chautan et al. 1999; Cande et al. 2002; Nagasaka et al. 2010). However, the caspase functions in mammalian morphogenetic processes remain to be studied in detail.

Genetic studies of caspase signaling in Drosophila revealed some interesting roles of caspases in morphogenetic processes. For example, apoptotic cell death may help generate the mechanical forces that drive cell movements and cell-shape changes during epithelial morphogenesis. During Drosophila embryonic development, a process called dorsal closure completes the sealing of the yolk and the amnioserosa. As the dorsal epidermis spreads and amnioserosa cells constrict, multiple forces drive the closure (Hutson et al. 2003). Apoptosis of amnioserosa cells may help generate one of the forces needed to seal the dorsal epithelium over the embryo (Toyama et al. 2008).

When a discontinuity in Dpp activity is generated between neighboring cells, JNK-dependent apoptosis is triggered to restore the appropriate cell-positional information (AdachiYamada et al. 1999). Similar mechanism is involved in the morphogenesis of the Drosophila leg joint (Manjon et al. 2007). During normal segmentation of the Drosophila distal legs, Dpp is expressed in the most distal part of every forming segment, and only diffuses proximally; the sharp boundary in Dpp activity induces JNK-dependent apoptosis, which leads to the epithelial folding that prefigures the adult joint (Manjon et al. 2007).

During Drosophila embryonic development, the Hox protein Deformed helps maintain the boundary between the maxillary and mandibular head lobes, by activating the celldeath-promoting gene reaper to induce localized apoptosis. Abdominal-B also regulates segment boundaries through the regional activation of apoptosis. Thus, apoptosis induced by Drosophila Hox genes modulates segmental morphology (Lohmann et al. 2002).

Global tissue rotation is a morphogenetic movement involved in controlling tissue elongation (Haigo and Bilder 2011). Drosophila apoptosis mutants show an orientation defect of the male terminalia. The male terminalia nor- mally rotates $360^{\circ}$ during development, and incomplete rotation causes the orientation defect of male terminalia (Macias et al. 2004). During development, the male genitalia rotation accelerates to complete the full $360^{\circ}$ rotation; this acceleration is impaired in apoptosisdefective flies (Abbott and Lengyel 1991; Benitez et al. 2010; Suzanne et al. 2010; Kuranaga et al. 2011). Genetic and live-imaging studies indicated the active roles of apoptosis in genitalia rotation (Suzanne et al. 2010; Kuranaga et al. 2011) and caspase drives the acceleration of genitalia rotation to complete the morphogenesis of male genitalia within a limited developmental window (Kuranaga et al. 2011).

\section{Caspases in Compensatory Proliferation and Regeneration}

Some animal tissues, including the limbs of urodele amphibians such as newts and salamanders, the tadpole tail of Xenopus, the heart and fin of fish (Johnson and Weston 1995; Akimenko et al. 2003; Poss 2007), Drosophila larval imaginal discs, and freshwater hydra, have a striking regenerative capacity. When such tissues are injured, many cells die by apoptosis. This apoptosis appears to be essential for the subsequent regenerative cell proliferation in hydra (Chera et al. 2009), planarians (Hwang et al. 2004; Pellettieri et al. 2010), Drosophila (Milan et al. 1997; Huh et al. 2004a; Ryoo et al. 2004), Xenopus (Tseng et al. 2007), newt (Vlaskalin et al. 2004), and mouse (Li et al. 2010c). Upon healing, a tissue's final shape and size often match those of the uninjured tissue, owing to a regenerative cell proliferation mechanism that is often called "compensatory proliferation" (Fig. 2).

The local induction of apoptosis by ectopic toxin expression in Drosophila wing imaginal disc results in elevated cell proliferation around the site of apoptosis, suggesting that cells can perceive apoptosis in their vicinity and undergo extra cell divisions until the original cell number is restored (Milan et al. 1997). When the Drosophila cell-death-inducing gene reaper $(r p r)$ or head involution defective (hid) is expressed, or imaginal discs are subjected to $\mathrm{X}$ rays together with baculovirus $p 35$ (a potent inhibitor of 
M. Miura

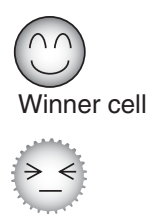

Loser cell

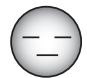

Dying cell

$\because \because$ :

Growth factor
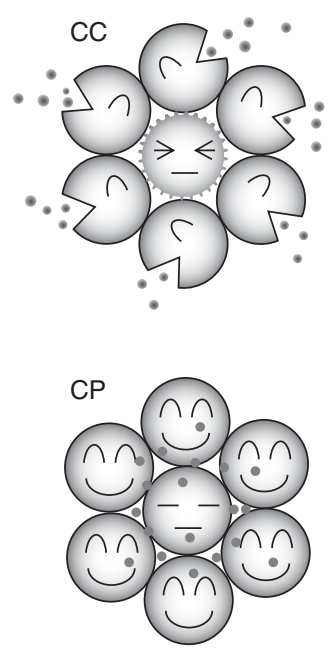

Figure 2. Cell competition (CC) and compensatory proliferation $(\mathrm{CP})$. In CC, a cell that receives less growth factor is eliminated by apoptosis. Dying cells release growth factors that promote the $\mathrm{CP}$ of neighboring cells.

effector caspases such as drice and dcp-1 but not of the initiator caspase dronc [Meier et al. 2000; Xu et al.2009]), the apoptosis-signaling cascade is activated only to the point in which dronc has been activated, and the cells fail to undergo apoptosis. Under these conditions, the proliferation regulators Wingless $(\mathrm{Wg})$ and Decapentaplegic (Dpp) are ectopically expressed (Huh et al. 2004a; Perez-Garijo et al. 2004, 2005; Ryoo et al. 2004; Kondo et al. 2006; Wells et al. 2006), and hyperplastic tissue growth occurs. In this experimental system, dronc was found to be required for proliferation and was suggested to be involved in the induction of mitogen expression in the proliferating cells of wing imaginal discs (Huh et al. 2004a; Kondo et al. 2006; Wells et al. 2006). In the differentiating cells of eye imaginal discs, effector caspases trigger the activation of Hedgehog (Hh) signaling for the compensatory proliferation (Fig. 3) (Fan and Bergmann 2008).

Classical tissue regeneration experiments were performed using Drosophila imaginal discs (Hadorn and Buck 1962; Hadorn et al. 1968). These tissue-ablation experiments required microsurgery skills and were technically difficult. Recently, nonsurgical, genetic ablation methods were used to study imaginal disc regeneration (Smith-Bolton et al. 2009; Bergantinos et al. 2010). Apoptosis induced in a portion of the wing imaginal disc by the transient expression of the cell-death-inducing gene reaper (diap1 antagonist) or eiger (TNF $\alpha$ ortholog) caused caspase activation and the extrusion of dying

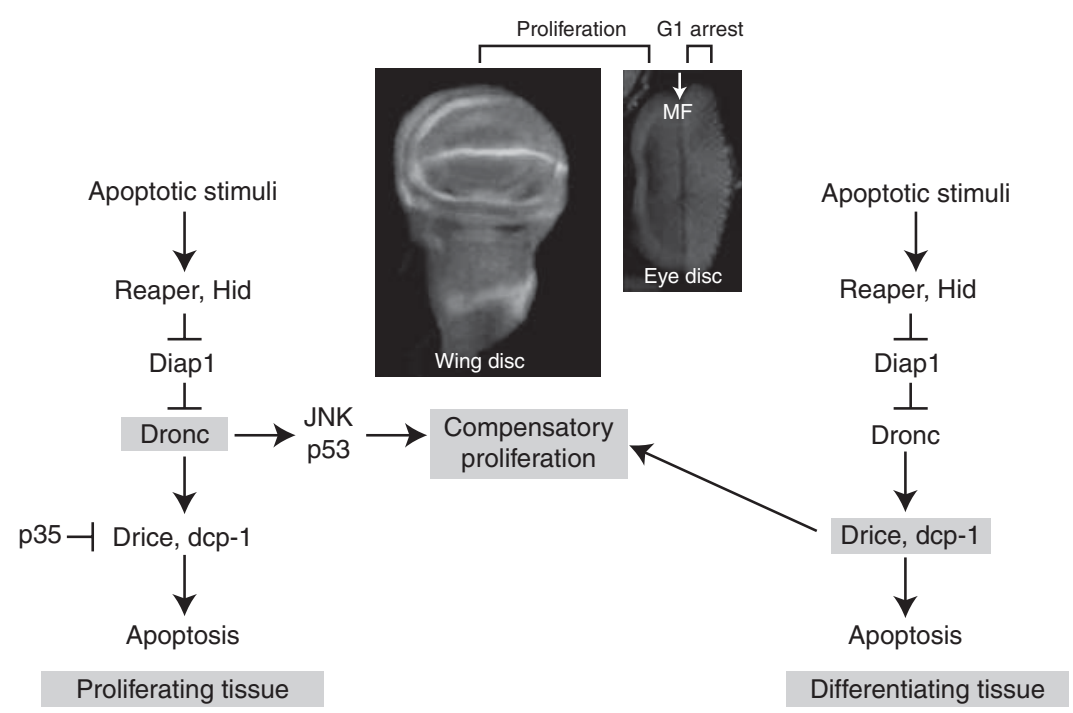

Figure 3. Genetic cascade of compensatory proliferation in proliferating or differentiating cells in Drosophila imaginal discs (wing and eye discs). 
Caspase Functions in Animal Development

cells from the epithelium. As the tissue healed, cytoskeletal reorganization was observed with JNK activation at the leading edges of the healing tissue, not in the dying cells; furthermore, JNK activation was required for compensatory proliferation of the regenerating tissue (Bergantinos et al. 2010). Unlike the proliferation observed when reaper and caspase inhibitor p35 are coexpressed in the wing imaginal disc, $\mathrm{Wg}$ is predominantly expressed in the proliferating cells, not in the dying cells during tissue regeneration (Smith-Bolton et al. 2009).

The relationship between apoptosis and compensatory proliferation was studied in Hydra during the regeneration after amputation (Chera et al. 2009). Mid-gastric bisection induces apoptosis specifically in the head, and not in the foot-regenerating region. Apoptotic cells in the head-regenerating region release Wnt3 to trigger compensatory proliferation and regeneration. The ectopic induction of apoptosis by heating in the foot-regenerating region activates the $\mathrm{Wnt} 3 / \beta$-Catenin pathway, and is sufficient to cause head formation. In both cases, treatment with the pan-caspase inhibitor Z-VAD abolishes the Wnt3/ $\beta$-Catenin pathway activation and head regeneration. These results showed that caspase-mediated signaling promotes compensatory proliferation in Hydra tissue regeneration.

In a mammalian wound-healing model, caspase-3- or caspase-7-deficient mice show defects in skin-wound healing and cell proliferation ( $\mathrm{Li}$ et al. 2010c). Caspase-3 and caspase-7 were also important for healing in partial-hepatectomy model mice. In caspase-3- or caspase-7-knockout mice, the regenerative cell proliferation was reduced about $50 \%$, indicating that executioner caspases are required for cell proliferation during wound healing and tissue regeneration $(\mathrm{Li}$ et al. 2010c). The growth signal from the caspase-activated cells might be prostaglandin E2 (PGE2). Calcium-independent phospholipase A2 (iPLA2), which produces arachidonic acid and triggers PGE2 production, is activated after cleavage by caspase-3 (Atsumi et al. 1998; Zhao et al. 2006). PGE2 is known to promote stemcell proliferation (Feher and Gidali 1974; Liou et al. 2007; North et al. 2007), tissue regenera- tion (Goessling et al. 2009), and wound healing (Kuhrer et al. 1986; Paralkar et al. 2003).

\section{Caspase in Tissue Growth Control}

During regeneration, the overall size of the recovering tissue is regulated. The mechanism of tissue-growth control has been studied in Drosophila wing discs. The central regulator of tissue size is insulin/TOR signaling, which ultimately controls the ribosome and protein synthesis. Conditional expression of the ribosomeinactivating protein Ricin toxin A chain in the posterior wing imaginal disc causes a nonautonomous reduction in the growth and proliferation rates of adjacent cell populations (Mesquita et al. 2010). In this condition, dronc activation, detected by an antibody against activated human caspase-3 (Fan and Bergmann 2009), is observed not only in the Ricin-expressing territories but also in adjacent cells (Mesquita et al. 2010). The coexpression of baculovirus p35 in the Ricin-expressing domain prevents cell death in that region and partially prevents it in the neighboring region. Thus, the cell proliferation is nonautonomously rescued, suggesting that effector caspases in the growth-depleted territory are required for the reduced cell proliferation in the adjacent cells. However, the nonautonomous reduction of overall tissue size is not rescued by the expression of $p 35$.

p53 is activated in the growth-deficient cells, and effector caspases are activated downstream of p53. As with p35 expression, a reduction in p53 activity in the Ricin-expressing territory nonautonomously rescues cell proliferation. However, unlike p35 expression, the adjacent tissue growth is rescued by $p 53$ suppression. Targeted Ricin-expression activates p53, which induces caspase activation. The tissue size and cell proliferation are regulated by $\mathrm{p} 53$ nonautonomously, but caspases have a unique role in regulating the proliferation of adjacent cell populations (Mesquita et al. 2010).

\section{Caspase in Cell Competition}

Cell competition was first discovered by genetic studies in Drosophila (Morata and Ripoll 1975; 
M. Miura

Simpson 1979; Simpson and Morata 1981). The genes for ribosomal proteins (RPs) are essential, and their homozygous mutations are lethal; however, their heterozygotes can result in the "Minute" dominant, haploinsufficient phenotypes, such as a slow growth rate and short and thin bristles (these heterozygous flies are called "Minute" because of their small bristles). When mosaic clones consisting of wild-type cells and Minute cells are generated in wing imaginal discs, the Minute cells are selectively eliminated by apoptosis, and wild-type cells eventually take over within a compartment (Fig. 2) (Morata and Ripoll 1975; Moreno et al. 2002). Thus, there is a competitive interaction between Minute cells (losers) and wild-type cells (winners). This elimination of Minute cells does not occur under starvation conditions (Simpson 1979), suggesting a link between the Minute mutation and nutrition control. Target of rapamycin complex 2 (TORC2) regulates cell survival and growth. TORC2 is activated by directly associating with a ribosome, suggesting there might be a direct link between Minute and growth-control mechanisms (Zinzalla et al. 2011). Cells carrying different dosages of the myc gene also show competitive interaction (de la Cova et al. 2004; Moreno and Basler 2004). High-myc cells are winners and low-myc cells are losers under competitive conditions. Because myc promotes the gene expression of ribosomal proteins, supercompetition by high myc might result from high ribosomal biosynthesis (Johnston 2009).

There are differences in the cell-competition processes induced by Minute and myc. The induction of cell death in Minute clones is initiated locally, whereas $m y c$-induced competition affects up to 10 cells (de la Cova et al. 2004; Li and Baker 2007). Both Minute and myc-induced competition preserves the wing size, indicating a balance between the growth of winner and the loss of loser cells. However, cell competition itself is not a major regulatory mechanism for wing size control. Rather, growth arrest that occurred once compartment size reached the final dimension plays significant role for size control (Martin et al. 2009).

The concept of cell competition can be extended to explain the competitive nature of cell populations in the body (Baker 2011). Mosaic clones of tumor-suppressor genes that encode proteins essential for establishing epithelial apicobasal polarity, such as scribble (scrib), discs large (dlg), and lethal giant larvae ( $\lg l)$, are eliminated by cell competition (Woods and Bryant 1991; Agrawal et al. 1995; Brumby and Richardson 2003; Igaki et al. 2006). The engulfment of loser cells by winner cells is required for cell death execution and cell elimination in both the Minute and scribble models of cell competition (Li and Baker 2007; Ohsawa et al. 2011). JNK is important for elimination of scribble clone, but caspases may not be (Brumby and Richardson 2003; Igaki et al. 2006), suggesting that caspase-dependent and -independent mechanisms are used for cell elimination in different types of cell competition. Caspase-independent elimination of scribble clones by cell competition is executed by Eiger/TNF signaling (Igaki et al. 2006, 2009). Cell death signaling by Eiger/TNF has a similarity with necroptosis (Degterev et al. 2005; Christofferson and Yuan 2010) and is regulated by JNK and energy metabolic pathway (Kanda et al. 2011).

\section{TISSUE REMODELING DURING DEVELOPMENT}

Although cell competition has been extensively studied by mosaic analysis in Drosophila wing imaginal discs, studies on the physiological nature of cell competition are still limited. One system for studying cell-competition-like phenomena in vivo is the abdominal epithelial replacement in Drosophila. The adult abdominal epidermis is formed by histoblasts, which replace the polyploid larval epidermal cells (LECs) during the pupal stage. About $15 \mathrm{~h}$ after puparium formation, the histoblast nests expand, and the histoblasts migrate collectively over the abdomen (Madhavan and Madhavan 1980). As in cell competition, the histoblasts behave like winners and replace the LECs, which undergo apoptosis, like losers. During abdominal epithelial replacement, the coordination of LEC apoptosis and histoblast proliferation enables the orderly substitution of cell types without changing the area of the epithelium, as in 
Caspase Functions in Animal Development

cell-competition experiments in wing discs. Possible mechanisms for the replacement of abdominal epithelium include mutual signaling events, mechanical forces, and cell competition (Ninov et al. 2007, 2010). A study of caspase activation during epithelial replacement in vivo at single-cell resolution indicated that caspase activation in LECs is induced at the LEC/ histoblast boundary, which expands as the LECs die. Transition from the S/G2 phases is necessary to induce nonautonomous LEC apoptosis at the LEC/histoblast boundary. This replacement boundary, formed as caspase activation is regulated locally by cell-cell communication, may drive the dynamic orchestration of cell replacement during tissue remodeling by competitive interaction (Fig. 4) (Nakajima et al. 2011).

\section{Nonapoptotic Caspase Functions}

Caspases exert nonapoptotic functions, which include roles in cell proliferation, migration, differentiation, and immunity (Kuranaga and Miura 2007; Yi and Yuan 2009). These functions are executed via three mechanisms.

\section{Local Activation of Caspases}

During neural development, some axons and dendrites degenerate or are pruned to create proper neural circuits. In Drosophila, dendritic pruning in class IV dendritic arborization sensory neurons occurs during metamorphosis. During this process, caspase activity is detected locally in the degenerating dendrites, and mutation of the initiator caspase dronc preserves most of the dendrite morphology (Kuo et al. 2006; Williams et al. 2006; Schoenmann et al. 2010). Mutations of effector caspases, such as drice or $d c p-1$, or expression of caspase inhibitor $p 35$, only weakly reduce dendritic pruning, suggesting that dronc promotes dendritic pruning by a mechanism other than the activation of effector caspases (Schoenmann et al. 2010). The dronc activation in this system is regulated by a diap1-degrading kinase, IK2/DmIKKع (Kuranaga et al. 2006; Lee et al. 2009a). Neuromuscular degeneration caused by disruption of the spectrin/ankyrin skeleton requires dronc, $d c p-1$, apaf-1 (dark), and bcl-2 family gene debcl (Keller et al. 2011). In contrast, caspase inhibition by p35 or diap1 fails to block axon pruning during Drosophila metamorphosis (Awasaki et al. 2006).

Caspases are reported to be involved in axon degeneration in mammals. Caspase- 6 but not caspase- 3 is activated after NGF deprivation in dissociated dorsal root ganglion (DRG) culture (Nikolaev et al. 2009), and caspase-6 inhibition alone can block the axonal degeneration. In a different DRG culture system, NGF deprivation induces axonal degradation and the activation

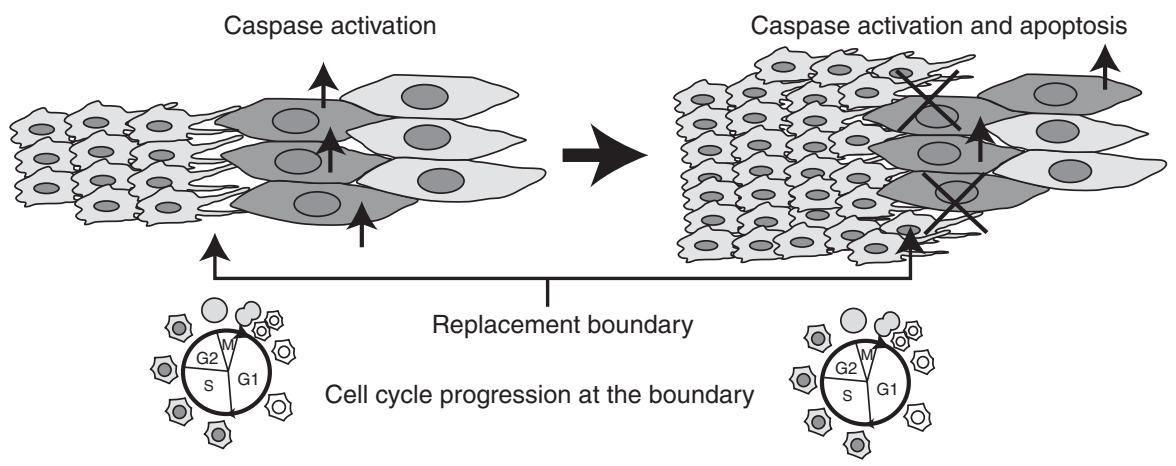

Figure 4. Ordered caspase activation during epidermal remodeling in Drosophila metamorphosis. Caspaseactivated cells (dark grey and arrow) at the "replacement boundary" are eliminated, and histoblast (small cell) cell-cycle progression is coupled with larval epidermal cell (large cell) apoptosis. Apoptosis at the replacement boundary creates a spatiotemporal pattern of tissue removal, and maintains the epithelial integrity as histoblasts replace larval epidermal cells. 
M. Miura

of both caspase- 3 and caspase- 6 in axons (Schoenmann et al. 2010). To completely protect the axons from degenerating, $\mathrm{NAD}^{+}$must be added to the DRG culture with caspase- 6 or caspase- 3 inhibitors. Because an $\mathrm{NAD}^{+}$-sensitive pathway is thought to be involved in Wallerian degeneration (Araki et al. 2004), caspasemediated and $\mathrm{NAD}^{+}$-sensitive pathways may act separately or in concert to control axonal degeneration. BAX acts upstream of both $\mathrm{NAD}^{+}$ and caspase pathways in DRG culture, and is required to eliminate misprojecting sensory axons in Plexin-A3/A4 double-knockout mice (Schoenmann et al. 2010).

In Xenopus, caspase- 3 is required for the growth cones in cultured retinal cells to respond to the chemotropic molecules Netrin-1- or lysophosphatidic acid (LPA) (Campbell and Holt 2003).

During sperm differentiation in Drosophila, 64 haploid spermatids of each cyst are connected by cytoplasmic bridges. To form individual sperm, these bridges are removed, and most of the cytoplasm is expelled. This process is called "individualization." Caspases are activated in the individualization complex, and their spatially dependent activation is necessary to complete this process (Arama et al. 2003, 2006, 2007; Huh et al. 2004b; Kaplan et al. 2010).

\section{Regulation of Endogenous Caspase Inhibitors}

Three Drosophila genes, reaper (rpr), head involution defective (hid), and grim, are key regulators of apoptosis during Drosophila embryogenesis (White et al. 1994). The overexpression of one of the three genes induces apoptosis via a caspase-activation pathway. Each of these proteins binds to diap1, an endogenous caspase inhibitor, through interactions mediated by their $\mathrm{NH}_{2}$ terminus. Genetic and biochemical data indicate that one way these proteins promote apoptosis is by inhibiting diap1's ability to prevent caspase activity (Gyrd-Hansen and Meier 2010; Sandu et al. 2010). The mammalian mitochondrial proteins Smac/DIABLO and HtrA2/ Omi, whose truncated $\mathrm{NH}_{2}$ terminus shares similarity with Rpr, Hid, and Grim, similarly inhibit the anti-apoptotic function of XIAP and enhance caspase activation (Gyrd-Hansen and Meier 2010).

A genetic modifier screen for genes that regulate caspase activation identified Drosophila IKK-related kinase (DmIKKe/IK2) as a diap1degrading kinase. DmIKKe is a homolog of the noncanonical IкB kinases (IKKe/IKKi or $\mathrm{NAK} / \mathrm{T} 2 \mathrm{~K} / \mathrm{TBK} 1$ ), which regulate NF- $\mathrm{KB}$ activation or interferon regulatory factor (IRF)-3 and -7 activation in mammals (Kawai and Akira 2006). A low-level caspase activity is detected in the scabrous-expressing proneural clusters in wild-type wing discs (Kanuka et al. 2005). Similar to the phenotype of $p 35$ or dronc-DN overexpression in proneural clusters, DmIKKe knockdown leads to the generation of one extra bristle in the scutellar region (Kuranaga et al. 2006). Thus, DmIKKe appears to control the level of diap1, which determines the nonapoptotic caspase activity required for defining the number of bristles as two in the proneural cluster of the scutellar region (Kuranaga et al. 2006). In addition, diap2 controls the basal caspaseactivity level for both apoptotic and nonapoptotic functions (Ribeiro et al. 2007).

\section{Temporal Caspase Activation}

A transient increase in caspase-3 activity is observed during neural-cell differentiation from neurospheres or PC12 cells (Rohn et al. 2004; Fernando et al. 2005). Caspase- 3 and caspase- 8 are transiently activated after the transduction of iPSC-inducing transcription factors, and caspase- 3 or caspase- 8 inhibition in human fibroblast cells prevents the iPSC induction, suggesting that transient, nonapoptotic caspase activities have critical roles in cell-fate reprogramming (Li et al. 2010b).

The diap1 expression is a critical regulator for the temporal caspase activation (Koto et al. 2009). To investigate the spatial and temporal pattern of diap 1 protein expression in vivo, a reporter protein for monitoring diap1 turnover, PRAP (pre-apoptosis signal-detecting probe, based on diap1 degradation) was developed. Live-imaging analysis of PRAP revealed that diap 1 degradation is regulated in a cell lineageand stage-specific manner during Drosophila 
sensory organ development. diap1 executes two distinct functions, one in shaft-cell survival just after the final division, and one in shaft-cell morphogenesis during its maturation stage. Both functions are exerted through the regulation of caspase activity. For the maturation stage, nonapoptotic dronc activity is required and regulated by DmIKKe. Thus, precise temporal control of the endogenous caspase inhibitor diap1 is critical for maintaining a balance between cell viability and the execution of caspases' nonapoptotic functions.

\section{CONCLUDING REMARKS}

Caspase activation that occurs on intrinsic and extrinsic stress during development and tissue regeneration supports the robust cell-fate determination of the cell community through both cell-autonomous mechanisms, such as execution of cell death or nonapoptotic functions. Caspase-mediated cell death also participates in development thorough noncell autonomous mechanisms, such as secretion of signaling molecules or force generation for neighboring cells. Thus, caspases actively participate in animal development as well as tissue regeneration.

\section{ACKNOWLEDGMENTS}

We apologize to colleagues whose work could not be cited owing to space limitations. I deeply thank the members of our laboratory for stimulating discussion, especially Y. Yamaguchi for critical reading.

\section{REFERENCES}

Abbott MK, Lengyel JA. 1991. Embryonic head involution and rotation of male terminalia require the Drosophila locus head involution defective. Genetics 129: 783-789.

Adachi M, Suematsu S, Kondo T, Ogasawara J, Tanaka T, Yoshida N, Nagata S. 1995. Targeted mutation in the Fas gene causes hyperplasia in peripheral lymphoid organs and liver. Nat Genet 11: 294-300.

Adachi-Yamada T, Fujimura-Kamada K, Nishida Y, Matsumoto K. 1999. Distortion of proximodistal information causes JNK-dependent apoptosis in Drosophila wing. Nature 400: 166-169.

Agrawal N, Kango M, Mishra A, Sinha P. 1995. Neoplastic transformation and aberrant cell-cell interactions in ge- netic mosaics of lethal(2)giant larvae (lgl), a tumor suppressor gene of Drosophila. Dev Biol 172: 218-229.

Akhter A, Gavrilin MA, Frantz L, Washington S, Ditty C, Limoli D, Day C, Sarkar A, Newland C, Butchar J, et al. 2009. Caspase-7 activation by the Nlrc4/Ipaf inflammasome restricts Legionella pneumophila infection. PLoS Pathog 5: e1000361.

Akimenko MA, Mari-Beffa M, Becerra J, Geraudie J. 2003. Old questions, new tools, and some answers to the mystery of fin regeneration. Dev Dyn 226: 190-201.

Al-Mashat HA, Kandru S, Liu R, Behl Y, Desta T, Graves DT. 2006. Diabetes enhances mRNA levels of proapoptotic genes and caspase activity, which contribute to impaired healing. Diabetes 55: 487-495.

Araki T, Sasaki Y, Milbrandt J. 2004. Increased nuclear NAD biosynthesis and SIRT1 activation prevent axonal degeneration. Science 305: 1010-1013.

Arama E, Agapite J, Steller H. 2003. Caspase activity and a specific cytochrome $\mathrm{C}$ are required for sperm differentiation in Drosophila. Dev Cell 4: 687-697.

Arama E, Bader M, Srivastava M, Bergmann A, Steller H. 2006. The two Drosophila cytochrome C proteins can function in both respiration and caspase activation. EMBO J 25: 232-243.

Arama E, Bader M, Rieckhof GE, Steller H. 2007. A ubiquitin ligase complex regulates caspase activation during sperm differentiation in Drosophila. PLoS Biol 5: e251.

Atsumi G, Tajima M, Hadano A, Nakatani Y, Murakami M, Kudo I. 1998. Fas-induced arachidonic acid release is mediated by $\mathrm{Ca}^{2+}$-independent phospholipase A2 but not cytosolic phospholipase A2, which undergoes proteolytic inactivation. J Biol Chem 273: 13870-13877.

Awasaki T, Tatsumi R, Takahashi K, Arai K, Nakanishi Y, Ueda R, Ito K. 2006. Essential role of the apoptotic cell engulfment genes draper and ced-6 in programmed axon pruning during Drosophila metamorphosis. Neuron 50: 855-867.

Baehrecke EH. 2000. Steroid regulation of programmed cell death during Drosophila development. Cell Death Differ 7: 1057-1062.

Baker NE. 2011. Cell competition. Curr Biol 21: R11-15.

Benitez S, Sosa C, Tomasini N, Macias A. 2010. Both JNK and apoptosis pathways regulate growth and terminalia rotation during Drosophila genital disc development. Int J Dev Biol 54: 643-653.

Bergantinos C, Corominas M, Serras F. 2010. Cell deathinduced regeneration in wing imaginal discs requires JNK signalling. Development 137: 1169-1179.

Berry DL, Baehrecke EH. 2007. Growth arrest and autophagy are required for salivary gland cell degradation in Drosophila. Cell 131: 1137-1148.

Boldin MP, Goncharov TM, Goltsev YV, Wallach D. 1996. Involvement of MACH, a novel MORT1/FADD-interacting protease, in Fas/APO-1- and TNF receptor-induced cell death. Cell 85: 803-815.

Brumby AM, Richardson HE. 2003. Scribble mutants cooperate with oncogenic Ras or Notch to cause neoplastic overgrowth in Drosophila. EMBO J 22: 5769-5779.

Buss RR, Sun W, Oppenheim RW. 2006. Adaptive roles of programmed cell death during nervous system development. Anпu Rev Neurosci 29: 1-35. 
M. Miura

Campbell DS, Holt CE. 2003. Apoptotic pathway and MAPKs differentially regulate chemotropic responses of retinal growth cones. Neuron 37: 939-952.

Cande C, Cecconi F, Dessen P, Kroemer G. 2002. Apoptosisinducing factor (AIF): Key to the conserved caspase-independent pathways of cell death? J Cell Sci 115(Pt 24): 4727-4734.

Cecconi F, Alvarez-Bolado G, Meyer BI, Roth KA, Gruss P. 1998. Apaf1 (CED-4 homolog) regulates programmed cell death in mammalian development. Cell 94: 727-737.

Chautan M, Chazal G, Cecconi F, Gruss P, Golstein P. 1999. Interdigital cell death can occur through a necrotic and caspase-independent pathway. Curr Biol 9: 967-970.

Chera S, Ghila L, Dobretz K, Wenger Y, Bauer C, Buzgariu W, Martinou JC, Galliot B. 2009. Apoptotic cells provide an unexpected source of Wnt 3 signaling to drive hydra head regeneration. Dev Cell 17: 279-289.

Chew SK, Akdemir F, Chen P, Lu WJ, Mills K, Daish T, Kumar S, Rodriguez A, Abrams JM. 2004. The apical caspase dronc governs programmed and unprogrammed cell death in Drosophila. Dev Cell 7: 897-907.

Cho YS, Challa S, Moquin D, Genga R, Ray TD, Guildford M, Chan FK. 2009. Phosphorylation-driven assembly of the RIP1-RIP3 complex regulates programmed necrosis and virus-induced inflammation. Cell 137: 1112-1123.

Christofferson DE, Yuan J. 2010. Necroptosis as an alternative form of programmed cell death. Curr Opin Cell Biol 22: $263-268$.

Cretney E, Takeda K, Yagita H, Glaccum M, Peschon JJ, Smyth MJ. 2002. Increased susceptibility to tumor initiation and metastasis in TNF-related apoptosis-inducing ligand-deficient mice. J Immunol 168: 1356-1361.

Daish TJ, Mills K, Kumar S. 2004. Drosophila caspase DRONC is required for specific developmental cell death pathways and stress-induced apoptosis. Dev Cell 7: 909-915.

Degterev A, Huang Z, Boyce M, Li Y, Jagtap P, Mizushima N, Cuny GD, Mitchison TJ, Moskowitz MA, Yuan J. 2005. Chemical inhibitor of nonapoptotic cell death with therapeutic potential for ischemic brain injury. Nat Chem Biol 1: 112-119.

de la Cova C, Abril M, Bellosta P, Gallant P, Johnston LA. 2004. Drosophila myc regulates organ size by inducing cell competition. Cell 117: 107-116.

Denton D, Shravage B, Simin R, Mills K, Berry DL, Baehrecke EH, Kumar S. 2009. Autophagy, not apoptosis, is essential for midgut cell death in Drosophila. Curr Biol 19: $1741-1746$.

Ellis HM, Horvitz HR. 1986. Genetic control of programmed cell death in the nematode C. elegans. Cell 44: 817-829.

Fan Y, Bergmann A. 2008. Distinct mechanisms of apoptosis-induced compensatory proliferation in proliferating and differentiating tissues in the Drosophila eye. Dev Cell 14: $399-410$.

Fan Y, Bergmann A. 2009. The cleaved-Caspase-3 antibody is a marker of Caspase-9-like DRONC activity in Drosophila. Cell Death Differ 17: 534-539.
Feher I, Gidali J. 1974. Prostaglandin E2 as stimulator of haemopoietic stem cell proliferation. Nature 247: 550551.

Feng S, Yang Y, Mei Y, Ma L, Zhu DE, Hoti N, Castanares M, Wu M. 2007. Cleavage of RIP3 inactivates its caspaseindependent apoptosis pathway by removal of kinase domain. Cell Signal 19: 2056-2067.

Fernando P, Brunette S, Megeney LA. 2005. Neural stem cell differentiation is dependent upon endogenous caspase 3 activity. FASEB J 19: 1671-1673.

Fraser AG, Evan GI. 1997. Identification of a Drosophila melanogaster ICE/CED-3-related protease, drICE. EMBO J 16: $2805-2813$.

Goessling W, North TE, Loewer S, Lord AM, Lee S, StoickCooper CL, Weidinger G, Puder M, Daley GQ, Moon RT, et al. 2009. Genetic interaction of PGE2 and Wnt signaling regulates developmental specification of stem cells and regeneration. Cell 136: 1136-1147.

Gyrd-Hansen M, Meier P. 2010. IAPs: From caspase inhibitors to modulators of NF- $\mathrm{\kappa B}$, inflammation and cancer. Nat Rev Cancer 10: 561-574.

Hadorn E, Buck D. 1962. Uber entwicklungsleistungen transplantierter teilstucke von flugel-imaginalscheiben von Drosophila melanogaster. Rev Suisse Zool 69: $302-$ 327.

Hadorn E, Hurlimann R, Mindek G, Schubiger G, Staub M. 1968. Developmental capacity of embryonalblastema in Drosophila following cultivation in adult host. Rev Suisse Zool 75: 557-569.

Haigo SL, Bilder D. 2011. Global tissue revolutions in a morphogenetic movement controlling elongation. Science 331: 1071-1074.

Hakem R, Hakem A, Duncan GS, Henderson JT, Woo M, Soengas MS, Elia A, de la Pompa JL, Kagi D, Khoo W, et al. 1998. Differential requirement for caspase 9 in apoptotic pathways in vivo. Cell 94: 339-352.

Huh JR, Guo M, Hay BA. 2004a. Compensatory proliferation induced by cell death in the Drosophila wing disc requires activity of the apical cell death caspase Dronc in a nonapoptotic role. Curr Biol 14: 1262-1266.

Huh JR, Vernooy SY, Yu H, Yan N, Shi Y, Guo M, Hay BA. 2004b. Multiple apoptotic caspase cascades are required in nonapoptotic roles for Drosophila spermatid individualization. PLoS Biol 2: E15.

Hutson MS, Tokutake Y, Chang MS, Bloor JW, Venakides S, Kiehart DP, Edwards GS. 2003. Forces for morphogenesis investigated with laser microsurgery and quantitative modeling. Science 300: 145-149.

Hwang JS, Kobayashi C, Agata K, Ikeo K, Gojobori T. 2004. Detection of apoptosis during planarian regeneration by the expression of apoptosis-related genes and TUNEL assay. Gene 333: 15-25.

Igaki T, Pagliarini RA, Xu T. 2006. Loss of cell polarity drives tumor growth and invasion through JNK activation in Drosophila. Curr Biol 16: 1139-1146.

Igaki T, Pastor-Pareja JC, Aonuma H, Miura M, Xu T. 2009. Intrinsic tumor suppression and epithelial maintenance by endocytic activation of Eiger/TNF signaling in Drosophila. Dev Cell 16: 458-465. 
Johnson SL, Weston JA. 1995. Temperature-sensitive mutations that cause stage-specific defects in Zebrafish fin regeneration. Genetics 141: 1583-1595.

Johnston LA. 2009. Competitive interactions between cells: Death, growth, and geography. Science 324: 1679-1682.

Kaiser WJ, Upton JW, Long AB, Livingston-Rosanoff D, Daley-Bauer LP, Hakem R, Caspary T, Mocarski ES. 2011. RIP3 mediates the embryonic lethality of caspase-8-deficient mice. Nature 471: 368-372.

Kanda H, Igaki T, Okano H, Miura M. 2011. Conserved metabolic energy production pathways govern Eiger/ TNF-induced nonapoptotic cell death. Proc Natl Acad Sci 108: 18977-18982.

Kang TB, Ben-Moshe T, Varfolomeev EE, Pewzner-Jung Y, Yogev N, Jurewicz A, Waisman A, Brenner O, Haffner R, Gustafsson E, et al. 2004. Caspase-8 serves both apoptotic and nonapoptotic roles. J Immunol 173: 2976-2984.

Kanuka H, Kuranaga E, Takemoto K, Hiratou T, Okano H, Miura M. 2005. Drosophila caspase transduces Shaggy/ GSK-3 $\beta$ kinase activity in neural precursor development. EMBO J 24: 3793-3806.

Kaplan Y, Gibbs-Bar L, Kalifa Y, Feinstein-Rotkopf Y, Arama E. 2010. Gradients of a ubiquitin E3 ligase inhibitor and a caspase inhibitor determine differentiation or death in spermatids. Dev Cell 19: 160-173.

Kawai T, Akira S. 2006. Innate immune recognition of viral infection. Nat Immunol 7: 131-137.

Keller LC, Cheng L, Locke CJ, Muller M, Fetter RD, Davis GW. 2011. Glial-derived prodegenerative signaling in the Drosophila neuromuscular system. Neuron 72 $760-775$.

Kondo S, Senoo-Matsuda N, Hiromi Y, Miura M. 2006. DRONC coordinates cell death and compensatory proliferation. Mol Cell Biol 26: 7258-7268.

Koto A, Kuranaga E, Miura M. 2009. Temporal regulation of Drosophila IAP1 determines caspase functions in sensory organ development. J Cell Biol 187: 219-231.

Koto A, Kuranaga E, Miura M. 2011. Apoptosis ensures spacing pattern formation of Drosophila sensory organs. Curr Biol 21: 278-287.

Kuhrer I, Kuzmits R, Linkesch W, Ludwig H. 1986. Topical PGE2 enhances healing of chemotherapy-associated mucosal lesions. Lancet 1: 623.

Kuida K, Zheng TS, Na S, Kuan C, Yang D, Karasuyama H, Rakic P, Flavell RA. 1996. Decreased apoptosis in the brain and premature lethality in CPP32-deficient mice. Nature 384: 368-372.

Kuida K, Haydar TF, Kuan CY, Gu Y, Taya C, Karasuyama H, Su MS, Rakic P, Flavell RA. 1998. Reduced apoptosis and cytochrome c-mediated caspase activation in mice lacking caspase 9. Cell 94: 325-337.

Kumar S, Doumanis J. 2000. The fly caspases. Cell Death Differ 7: 1039-1044.

Kuo CT, Zhu S, Younger S, Jan LY, Jan YN. 2006. Identification of E2/E3 ubiquitinating enzymes and caspase activity regulating Drosophila sensory neuron dendrite pruning. Neuron 51: 283-290.

Kuranaga E, Miura M. 2007. Nonapoptotic functions of caspases: caspases as regulatory molecules for immunity and cell-fate determination. Trends Cell Biol 17: 135-144.
Kuranaga E, Kanuka H, Tonoki A, Takemoto K, Tomioka T, Kobayashi M, Hayashi S, Miura M. 2006. Drosophila IKKrelated kinase regulates nonapoptotic function of caspases via degradation of IAPs. Cell 126: 583-596.

Kuranaga E, Matsunuma T, Kanuka H, Takemoto K, Koto A, Kimura K, Miura M. 2011. Apoptosis controls the speed of looping morphogenesis in Drosophila male terminalia. Development 138: 1493-1499.

Lakhani SA, Masud A, Kuida K, Porter GA Jr, Booth CJ, Mehal WZ, Inayat I, Flavell RA. 2006. Caspases 3 and 7 : Key mediators of mitochondrial events of apoptosis. Science 311: 847-851.

Lamkanfi M, Kanneganti TD, Van Damme P, Vanden Berghe T, Vanoverberghe I, Vandekerckhove J, Vandenabeele P, Gevaert K, Nunez G. 2008. Targeted peptidecentric proteomics reveals caspase- 7 as a substrate of the caspase-1 inflammasomes. Mol Cell Proteomics 7: 23502363.

Lee HH, Jan LY, Jan YN. 2009a. Drosophila IKK-related kinase Ik2 and Katanin p60-like 1 regulate dendrite pruning of sensory neuron during metamorphosis. Proc Natl Acad Sci 106: 6363-6368.

Lee P, Lee DJ, Chan C, Chen SW, Ch'en I, Jamora C. 2009b. Dynamic expression of epidermal caspase 8 simulates a wound healing response. Nature 458: 519-523.

Leonard JR, Klocke BJ, D'Sa C, Flavell RA, Roth KA. 2002. Strain-dependent neurodevelopmental abnormalities in caspase-3-deficient mice. J Neuropathol Exp Neurol 61: 673-677.

Leulier F, Ribeiro PS, Palmer E, Tenev T, Takahashi K, Robertson D, Zachariou A, Pichaud F, Ueda R, Meier P. 2006. Systematic in vivo RNAi analysis of putative components of the Drosophila cell death machinery. Cell Death Differ 13: 1663-1674.

Li W, Baker NE. 2007. Engulfment is required for cell competition. Cell 129: 1215-1225.

Li C, Lasse S, Lee P, Nakasaki M, Chen SW, Yamasaki K, Gallo RL, Jamora C. 2010a. Development of atopic dermatitis-like skin disease from the chronic loss of epidermal caspase-8. Proc Natl Acad Sci 107: 22249-22254.

Li F, He Z, Shen J, Huang Q, Li W, Liu X, He Y, Wolf F, Li CY. 2010b. Apoptotic caspases regulate induction of iPSCs from human fibroblasts. Cell Stem Cell 7: 508-520.

Li F, Huang Q, Chen J, Peng Y, Roop DR, Bedford JS, Li CY. 2010c. Apoptotic cells activate the "phoenix rising" pathway to promote wound healing and tissue regeneration. Sci Signal 3: ra13.

Lindsten T, Thompson CB. 2006. Cell death in the absence of Bax and Bak. Cell Death Differ 13: 1272-1276.

Lindsten T, Ross AJ, King A, Zong WX, Rathmell JC, Shiels HA, Ulrich E, Waymire KG, Mahar P, Frauwirth K, et al. 2000. The combined functions of proapoptotic Bcl2 family members bak and bax are essential for normal development of multiple tissues. Mol Cell 6: 1389-1399.

Liou JY, Ellent DP, Lee S, Goldsby J, Ko BS, Matijevic N, Huang JC, Wu KK. 2007. Cyclooxygenase-2-derived prostaglandin e 2 protects mouse embryonic stem cells from apoptosis. Stem Cells 25: 1096-1103.

Liu J, Na S, Glasebrook A, Fox N, Solenberg PJ, Zhang Q, Song HY, Yang DD. 2001. Enhanced CD4 ${ }^{+}$T cell 
M. Miura

proliferation and Th2 cytokine production in DR6-deficient mice. Immunity 15: 23-34.

Lohmann I, McGinnis N, Bodmer M, McGinnis W. 2002. The Drosophila Hox gene deformed sculpts head morphology via direct regulation of the apoptosis activator reaper. Cell 110: 457-466.

Macias A, Romero NM, Martin F, Suarez L, Rosa AL, Morata G. 2004. PVF1/PVR signaling and apoptosis promotes the rotation and dorsal closure of the Drosophila male terminalia. Int J Dev Biol 48: 1087-1094.

Madhavan MM, Madhavan K. 1980. Morphogenesis of the epidermis of adult abdomen of Drosophila. J Embryol Exp Morphol 60: 1-31.

Manjon C, Sanchez-Herrero E, Suzanne M. 2007. Sharp boundaries of Dpp signalling trigger local cell death required for Drosophila leg morphogenesis. Nat Cell Biol 9: 57-63.

Martin FA., Herrera SC., Morata G. 2009. Cell competition, growth and size control in the Drosophila wing imaginal disc. Development 136: 3747-3756.

Meier P, Silke J, Leevers SJ, Evan GI. 2000. The Drosophila caspase DRONC is regulated by DIAP1. EMBO J 19: $598-611$.

Mesquita D, Dekanty A, Milan M. 2010. A dp53-dependent mechanism involved in coordinating tissue growth in Drosophila. PLoS Biol 81000566.

Milan M, Campuzano S, Garcia-Bellido A. 1997. Developmental parameters of cell death in the wing disc of Drosophila. Proc Natl Acad Sci 94: 5691-5696.

Miura M. 2011. Active participation of cell death in development and organismal homeostasis. Dev Growth Differ 53: $125-136$.

Morata G, Ripoll P. 1975. Minutes: Mutants of Drosophila autonomously affecting cell division rate. Dev Biol 42: 211-221.

Moreno E, Basler K. 2004. dMyc transforms cells into supercompetitors. Cell 117: 117-129.

Moreno E, Basler K, Morata G. 2002. Cells compete for decapentaplegic survival factor to prevent apoptosis in Drosophila wing development. Nature 416: 755-759.

Muro I, Berry DL, Huh JR, Chen CH, Huang H, Yoo SJ, Guo M, Baehrecke EH, Hay BA. 2006. The Drosophila caspase Ice is important for many apoptotic cell deaths and for spermatid individualization, a nonapoptotic process. Development 133: 3305-3315.

Muzio M, Chinnaiyan AM, Kischkel FC, O'Rourke K, Shevchenko A, Ni J, Scaffidi C, Bretz JD, Zhang M, Gentz R, et al. 1996. FLICE, a novel FADD-homologous ICE/CED-3-like protease, is recruited to the CD95 (Fas/ APO-1) death-inducing signaling complex. Cell 85: 817-827.

Nagasaka A, Kawane K, Yoshida H, Nagata S. 2010. Apaf-1independent programmed cell death in mouse development. Cell Death Differ 17: 931-941.

Nakajima Y, Kuranaga E, Sugimura K, Miyawaki A, Miura M. 2011. Nonautonomous apoptosis is triggered by local cell cycle progression during epithelial replacement in Drosophila. Mol Cell Biol 31: 2499-2512.

Nikolaev A, McLaughlin T, O’Leary DD, Tessier-Lavigne M. 2009. APP binds DR6 to trigger axon pruning and neuron death via distinct caspases. Nature 457: 981-989.
Ninov N, Chiarelli DA, Martin-Blanco E. 2007. Extrinsic and intrinsic mechanisms directing epithelial cell sheet replacement during Drosophila metamorphosis. Development 134: 367-379.

Ninov N, Menezes-Cabral S, Prat-Rojo C, Manjon C, Weiss A, Pyrowolakis G, Affolter M, Martin-Blanco E. 2010. Dpp signaling directs cell motility and invasiveness during epithelial morphogenesis. Curr Biol 20: 513-520.

North TE, Goessling W, Walkley CR, Lengerke C, Kopani KR, Lord AM, Weber GJ, Bowman TV, Jang IH, Grosser T, et al. 2007. Prostaglandin E2 regulates vertebrate haematopoietic stem cell homeostasis. Nature 447: 1007-1011.

Oberst A, Dillon CP, Weinlich R, McCormick LL, Fitzgerald P, Pop C, Hakem R, Salvesen GS, Green DR. 2011. Catalytic activity of the caspase-8-FLIP(L) complex inhibits RIPK3-dependent necrosis. Nature 471: $363-$ 367.

Ohsawa S, Hamada S, Asou H, Kuida K, Uchiyama Y, Yoshida H, Miura M. 2009. Caspase-9 activation revealed by semaphorin 7A cleavage is independent of apoptosis in the aged olfactory bulb. J Neurosci 29: 11385-11392.

Ohsawa S, Hamada S, Kuida K, Yoshida H, Igaki T, Miura M. 2010. Maturation of the olfactory sensory neurons by Apaf-1/caspase-9-mediated caspase activity. Proc Natl Acad Sci 107: 13366-13371.

Ohsawa S, Sugimura K, Takino K, Xu T, Miyawaki A, Igaki T. 2011. Elimination of oncogenic neighbors by JNK-mediated engulfment in Drosophila. Dev Cell 20: 315-328.

Paralkar VM, Borovecki F, Ke HZ, Cameron KO, Lefker B, Grasser WA, Owen TA, Li M, DaSilva-Jardine P, Zhou M, et al. 2003. An EP2 receptor-selective prostaglandin E2 agonist induces bone healing. Proc Natl Acad Sci 100: 6736-6740.

Pellettieri J, Fitzgerald P, Watanabe S, Mancuso J, Green DR, Sanchez Alvarado A. 2010. Cell death and tissue remodeling in planarian regeneration. Dev Biol 338: 76-85.

Perez-Garijo A, Martin FA, Morata G. 2004. Caspase inhibition during apoptosis causes abnormal signalling and developmental aberrations in Drosophila. Development 131: 5591-5598.

Perez-Garijo A, Martin FA, Struhl G, Morata G. 2005. Dpp signaling and the induction of neoplastic tumors by caspase-inhibited apoptotic cells in Drosophila. Proc Natl Acad Sci 102: 17664-17669.

Pfeffer K, Matsuyama T, Kundig TM, Wakeham A, Kishihara K, Shahinian A, Wiegmann K, Ohashi PS, Kronke M, Mak TW. 1993. Mice deficient for the $55 \mathrm{kd}$ tumor necrosis factor receptor are resistant to endotoxic shock, yet succumb to L. monocytogenes infection. Cell 73: $457-467$.

Poss KD. 2007. Getting to the heart of regeneration in zebrafish. Semin Cell Dev Biol 18: 36-45.

Rebe C, Cathelin S, Launay S, Filomenko R, Prevotat L, L'Ollivier C, Gyan E, Micheau O, Grant S, DubartKupperschmitt A, et al. 2007. Caspase-8 prevents sustained activation of NF- $\kappa \mathrm{B}$ in monocytes undergoing macrophagic differentiation. Blood 109: 1442-1450.

Ren D, Tu HC, Kim H, Wang GX, Bean GR, Takeuchi O, Jeffers JR, Zambetti GP, Hsieh JJ, Cheng EH. 2010. BID, BIM, and PUMA are essential for activation of the BAX- 
and BAK-dependent cell death program. Science 330: 1390-1393.

Ribeiro PS, Kuranaga E, Tenev T, Leulier F, Miura M, Meier P. 2007. DIAP2 functions as a mechanism-based regulator of drICE that contributes to the caspase activity threshold in living cells. J Cell Biol 179: 1467-1480.

Rohn TT, Cusack SM, Kessinger SR, Oxford JT. 2004. Caspase activation independent of cell death is required for proper cell dispersal and correct morphology in PC12 cells. Exp Cell Res 295: 215-225.

Rothe J, Lesslauer W, Lotscher H, Lang Y, Koebel P, Kontgen F, Althage A, Zinkernagel R, Steinmetz M, Bluethmann H. 1993. Mice lacking the tumour necrosis factor receptor 1 are resistant to TNF-mediated toxicity but highly susceptible to infection by Listeria monocytogenes. Nature 364: 798-802.

Ryoo HD, Gorenc T, Steller H. 2004. Apoptotic cells can induce compensatory cell proliferation through the JNK and the Wingless signaling pathways. Dev Cell 7: 491-501.

Sakamaki K, Inoue T, Asano M, Sudo K, Kazama H, Sakagami J, Sakata S, Ozaki M, Nakamura S, Toyokuni S, et al. 2002. Ex vivo whole-embryo culture of caspase-8deficient embryos normalize their aberrant phenotypes in the developing neural tube and heart. Cell Death Differ 9: $1196-1206$.

Sandu C, Ryoo HD, Steller H. 2010. Drosophila IAP antagonists form multimeric complexes to promote cell death. J Cell Biol 190: 1039-1052.

Schoenmann Z, Assa-Kunik E, Tiomny S, Minis A, HaklaiTopper L, Arama E, Yaron A. 2010. Axonal degeneration is regulated by the apoptotic machinery or a $\mathrm{NAD}^{+}$-sensitive pathway in insects and mammals. J Neurosci 30: 6375-6386.

Simpson P. 1979. Parameters of cell competition in the compartments of the wing disc of Drosophila. Dev Biol 69: $182-193$.

Simpson P, Morata G. 1981. Differential mitotic rates and patterns of growth in compartments in the Drosophila wing. Dev Biol 85: 299-308.

Smith-Bolton RK, Worley MI, Kanda H, Hariharan IK. 2009. Regenerative growth in Drosophila imaginal discs is regulated by Wingless and Myc. Dev Cell 16: 797-809.

Sordet O, Rebe C, Plenchette S, Zermati Y, Hermine O, Vainchenker W, Garrido C, Solary E, Dubrez-Daloz L. 2002. Specific involvement of caspases in the differentiation of monocytes into macrophages. Blood 100: 44464453.

Strasser A, Puthalakath H, O'Reilly LA, Bouillet P. 2008. What do we know about the mechanisms of elimination of autoreactive Tand B cells and what challenges remain. Immunol Cell Biol 86: 57-66.

Suzanne M, Petzoldt AG, Speder P, Coutelis JB, Steller H, Noselli S. 2010. Coupling of apoptosis and L/R patterning controls stepwise organ looping. Curr Biol 20: 1773-1778.

Takemoto K, Kuranaga E, Tonoki A, Nagai T, Miyawaki A Miura M. 2007. Local initiation of caspase activation in Drosophila salivary gland programmed cell death in vivo. Proc Natl Acad Sci 104: 13367-13372.
Teixeira VH, Jacq L, Lasbleiz S, Hilliquin P, Oliveira CR, Cornelis F, Petit-Teixeira E. 2008. Genetic and expression analysis of CASP7 gene in a European Caucasian population with rheumatoid arthritis. J Rheumatol 35: 1912 1918.

Toyama Y, Peralta XG, Wells AR, Kiehart DP, Edwards GS. 2008. Apoptotic force and tissue dynamics during Drosophila embryogenesis. Science 321: 1683-1686.

Tseng AS, Adams DS, Qiu D, Koustubhan P, Levin M. 2007. Apoptosis is required during early stages of tail regeneration in Xenopus laevis. Dev Biol 301: 62-69.

Varfolomeev EE, Schuchmann M, Luria V, Chiannilkulchai N, Beckmann JS, Mett IL, Rebrikov D, Brodianski VM, Kemper OC, Kollet O, et al. 1998. Targeted disruption of the mouse Caspase 8 gene ablates cell death induction by the TNF receptors, Fas/Apol, and DR3 and is lethal prenatally. Immunity 9: 267-276.

Vlaskalin T, Wong CJ, Tsilfidis C. 2004. Growth and apoptosis during larval forelimb development and adult forelimb regeneration in the newt (Notophthalmus viridescens). Dev Genes Evol 214: 423-431.

Waldhuber M, Emoto K, Petritsch C. 2005. The Drosophila caspase DRONC is required for metamorphosis and cell death in response to irradiation and developmental signals. Mech Dev 122: 914-927.

Walsh JG, Cullen SP, Sheridan C, Luthi AU, Gerner C, Martin SJ. 2008. Executioner caspase-3 and caspase-7 are functionally distinct proteases. Proc Natl Acad Sci 105: $12815-12819$.

Wang EC, Thern A, Denzel A, Kitson J, Farrow SN, Owen MJ. 2001. DR3 regulates negative selection during thymocyte development. Mol Cell Biol 21: 3451-3461.

Wells BS, Yoshida E, Johnston LA. 2006. Compensatory proliferation in Drosophila imaginal discs requires Dronc-dependent p53 activity. Curr Biol 16: 1606-1615.

White K, Grether ME, Abrams JM, Young L, Farrell K, Steller H. 1994. Genetic control of programmed cell death in Drosophila. Science 264: 677-683.

Williams DW, Kondo S, Krzyzanowska A, Hiromi Y, Truman JW. 2006. Local caspase activity directs engulfment of dendrites during pruning. Nat Neurosci 9: 1234-1236.

Woods DF, Bryant PJ. 1991. The discs-large tumor suppressor gene of Drosophila encodes a guanylate kinase homolog localized at septate junctions. Cell 66: 451-464.

Xu D, Li Y, Arcaro M, Lackey M, Bergmann A. 2005. The CARD-carrying caspase Dronc is essential for most, but not all, developmental cell death in Drosophila. Development 132: 2125-2134.

Xu D, Wang Y, Willecke R, Chen Z, Ding T, Bergmann A. 2006. The effector caspases drICE and dcp-1 have partially overlapping functions in the apoptotic pathway in Drosophila. Cell Death Differ 13: 1697-1706.

Xu D, Woodfield SE, Lee TV, Fan Y, Antonio C, Bergmann A. 2009. Genetic control of programmed cell death (apoptosis) in Drosophila. Fly (Austin) 3: 78-90.

Yamaguchi Y, Shinotsuka N, Nonomura K, Takemoto K, Kuida K, Yosida H, Miura M. 2011. Live imaging of apoptosis in a novel transgenic mouse highlights its role in neural tube closure. J Cell Biol 195: 1047-1060. 


\section{Miura}

Yeh WC, Pompa JL, McCurrach ME, Shu HB, Elia AJ, Shahinian A, Ng M, Wakeham A, Khoo W, Mitchell K, et al. 1998. FADD: Essential for embryo development and signaling from some, but not all, inducers of apoptosis. Science 279: 1954-1958.

Yeh WC, Itie A, Elia AJ, Ng M, Shu HB, Wakeham A, Mirtsos C, Suzuki N, Bonnard M, Goeddel DV, et al. 2000. Requirement for Casper (c-FLIP) in regulation of death receptor-induced apoptosis and embryonic development. Immunity 12: 633-642.

Yi CH, Yuan J. 2009. The Jekyll and Hyde functions of caspases. Dev Cell 16: 21-34.

Yoshida H, Kong YY, Yoshida R, Elia AJ, Hakem A, Hakem R, Penninger JM, Mak TW. 1998. Apaf1 is required for mitochondrial pathways of apoptosis and brain development. Cell 94: 739-750.
Zhang J, Cado D, Chen A, Kabra NH, Winoto A. 1998. Fasmediated apoptosis and activation-induced T-cell proliferation are defective in mice lacking FADD/Mort1. $\mathrm{Na}$ ture 392: 296-300.

Zhang H, Zhou X, McQuade T, Li J, Chan FK, Zhang J. 2011. Functional complementation between FADD and RIP1 in embryos and lymphocytes. Nature 471: $373-376$.

Zhao X, Wang D, Zhao Z, Xiao Y, Sengupta S, Zhang R, Lauber K, Wesselborg S, Feng L, Rose TM, et al. 2006. Caspase-3-dependent activation of calcium-independent phospholipase A2 enhances cell migration in non-apoptotic ovarian cancer cells. J Biol Chem 281: 29357-29368.

Zinzalla V, Stracka D, Oppliger W, Hall MN. 2011. Activation of mTORC2 by association with the ribosome. Cell 144: $757-768$. 


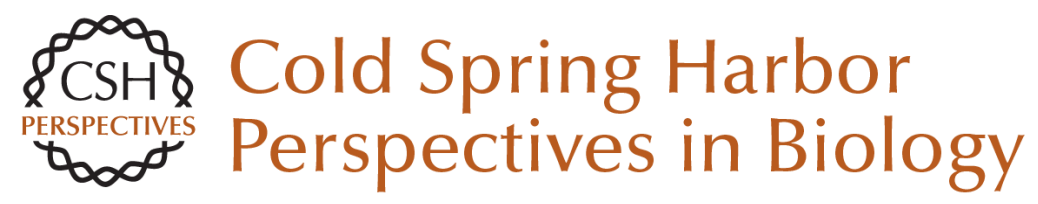

\section{Apoptotic and Nonapoptotic Caspase Functions in Animal Development}

Masayuki Miura

Cold Spring Harb Perspect Biol 2012; doi: 10.1101/cshperspect.a008664

Subject Collection Cell Survival and Cell Death

Programmed Cell Death in the Evolutionary Race against Bacterial Virulence Factors

Carolyn A. Lacey and Edward A. Miao

The Evolutionary Origins of Programmed Cell

Death Signaling

Kay Hofmann

Regulation of Cell Death and Immunity by XIAP Philipp J. Jost and Domagoj Vucic

Dysregulation of Cell Death in Human Chronic Inflammation

Yue Li, Christoph Klein and Daniel Kotlarz

Cell Death in Plant Immunity

Eugenia Pitsili, Ujjal J. Phukan and Nuria S. Coll

Recent Insights on Inflammasomes, Gasdermin

Pores, and Pyroptosis

Nathalia M. de Vasconcelos and Mohamed Lamkanfi

Phagocyte Responses to Cell Death in Flies Andrew J. Davidson and Will Wood

Mechanism and Regulation of Gasdermin-Mediated Cell Death

Shiyu Xia, Louis Robert Hollingsworth IV and Hao
Cell Death and Neurodegeneration

Benjamin J. Andreone, Martin Larhammar and Joseph W. Lewcock

Death Receptors and Their Ligands in

Inflammatory Disease and Cancer Alessandro Annibaldi and Henning Walczak

The Killer Pseudokinase Mixed Lineage Kinase Domain-Like Protein (MLKL) James M. Murphy

Neutrophil Extracellular Traps in Host Defense Sabrina Sofia Burgener and Kate Schroder

Cell-Cycle Cross Talk with Caspases and Their

Substrates

Patrick Connolly, Irmina Garcia-Carpio and Andreas Villunger

Cracking the Cell Death Code

Carla V. Rothlin and Sourav Ghosh

BAX, BAK, and BOK: A Coming of Age for the BCL-2 Family Effector Proteins

Tudor Moldoveanu and Peter E. Czabotar

Multitasking Kinase RIPK1 Regulates Cell Death and Inflammation

Kim Newton

For additional articles in this collection, see http://cshperspectives.cshlp.org/cgi/collection/

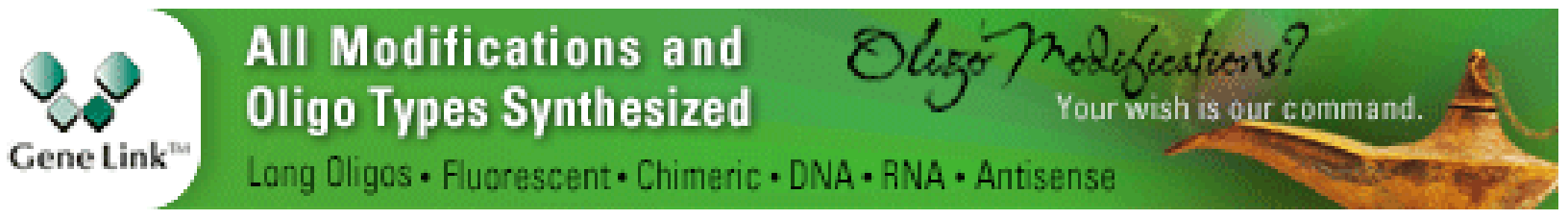


For additional articles in this collection, see http://cshperspectives.cshlp.org/cgi/collection/

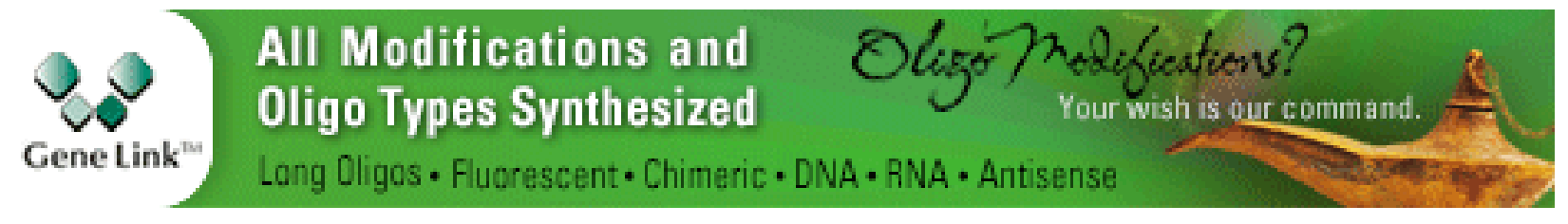

Copyright @ 2012 Cold Spring Harbor Laboratory Press; all rights reserved 